\title{
Forest Policy for Sustainability of Sri Lanka's Forest
}

\section{Ekanayake Mudiyanselage Buddhika Piumali Ekanayake1 Murindahabi Theodore ${ }^{2}$}

\author{
${ }^{1}$ School of Economics and Management ,Beijing Forestry University, No35,Qinghua East Road, Haidian District, \\ Beijing, Peoples Republic of china, Post Code -100083 \\ ${ }^{2}$ School of Economics and Management ,Beijing Forestry University,No35,Qinghua East Road, Haidian District, \\ Beijing, Peoples Republic of china, Post Code -100083
}

\begin{abstract}
The concept of sustainable forest management has emerged in early 1990s' as a vision of forest management in all over the world. In Sri Lanka, avoiding deforestation and improving the forest resources are the preliminary step towards sustainable forest management. Forest policies and strategies that were taken at various times gave greater concerns to solve deforestation problem and improve forest resources through sustainable manner. This paper attempts to discuss National forest policy of Sri Lanka and explore forest policy on sustainable management of forestry resources which are under the supervision of forest Department. Furthermore this paper makes some recommendation for better implementation of forest policies for future sustainability in the state forest resources. The Forest policy in Sri Lanka has changed with the time. The history of establishment of policies for the management of forest was stated in King Devanampiyatissa period of 246 B.C. Ancient agrarian society utilize forest and forest product, while maintaining its ecological balance. The first scientific policy for forestry sector in Sri Lanka was formulated by the British in 1929. The main objective of this forest policy is forest management focused on maximum out of quality timber. After the independent in Sri Lanka from the British in 1948, policy for forestry sector was modified in 1953, 1980 and later in 1995 The priorities of the policy changes focus on conservation of natural value of forest, raise the unit productivity of the forests land and enhance beneficial of the rural population.Forest Department with limited human and other resources, hierarchical management structure, political influence, lack of policy and lack of institutional and community support has recognized the requirement of appropriate policies, institutional reform and capacity building for promote sustainable livelihood and Sustainable forest management.
\end{abstract}

Keywords: Forest, Forest policy, Sustainability, Sri Lanka

\section{Introduction}

Forests are essential for the affluence of living on earth. All ecological activities and functions in the forest provide the substrate for life on earth. On behalf of human being forest Provide wood, nonwood products and environmental services which are demanded by the people. It is quite evidence that satisfactory extent of forest should prevail for the existence of life on earth, but the deforestation and forest degradation due to various reasons has endangered the very existence of Forest. Consequences of the destruction caused to the nature are common to those who are indulged in the act, to the others who are innocent and to all living beings on the earth without reservation. Therefore the loss and degradation of forest no longer concern only affected nation but also of the global community.
Hens, destruction of forest is the topic of major global discussion. Also numerous activities and efforts have made to avoid deforestation.

At the beginning of 1990s, the new concept of forest management has emerged in world. It is sustainable forest management (SFM). United nation define SFM as dynamic and evolving concept that aims to maintain and enhance the environmental, economical and social values of all types of forest for meet the needs of present and future generation (F.A.O, 2016) .The concept of SFM address overall structural and functional systems in the Forestry sector such as economical, legal, social, technical and scientific aspects and administration.

This article is published under the terms of the Creative Commons Attribution License 4.0

Author(s) retain the copyright of this article. Publication rights with Alkhaer Publications.

Published at: http://www.ijsciences.com/pub/issue/2017-01/

DOI: 10.18483/ijSci.1174; Online ISSN: 2305-3925; Print ISSN: 2410-4477 
For the Sustainability of forestry sector, avoiding deforestation is vital. The conversion of forest land in to an alternative none forest land use systems such as agriculture, grazing or urban development is called as Deforestation (Kooten and Bulte, 2000). For several decades, Sri Lankan forests have been deforested both legally and illegally due to rapid population growth. The forest reserve of nearly $84 \%$ in 1984 was reduced to $29.7 \%$ in 2010 . Huge demand of land for settlement schemes, Economic purposes, agriculture, Timber production and Weak enforcement of land use policies are main issues of forest degradation (Gunatilake, 1998). 25 years civil war ended in 2009 also contribute to deforestation by increasing the demand for resettlement land. Depleting and degrading natural resources at an alarming rate is the major consequence of deforestation. Other than that loss of habitat, water scarcity, nutrition depletion and Soil erosion are common facts.

Under the framework of Sustainable forestry, Sri Lanka Forestry sector at present appears more conservation oriented. The best method to conserve forest is to adopt the participatory approach. Those who do not co-operative with this approach should be brought before the law. Therefore legal restriction and forest sector policies have provide great protection for countries forestry sector.

This paper aims to review National forest policy of Sri Lanka and explore forest policy on sustainable management of state forest resources under the jurisdiction of the Department of Forest conservation in Sri Lanka. Furthermore this paper makes some recommendation for better implementation of forest policies for future sustainability in the state forest resources.

\section{Sri Lanka's Forest cover and Ownership}

the island of Sri Lanka, which lies between $5^{\circ} 55^{\prime}$ $9^{\circ} 50^{\prime}$ North and $79^{\circ} 42^{\prime}-81^{\circ} 55^{\prime}$ East, covers an area of $65525 \mathrm{~km}^{2}$. Sri Lanka is a densely populated country. In 2015 total population is 21 million, giving an average population density of 334 persons $/ \mathrm{km}^{2}$. (World Bank, 2015)

Same as other countries, Forest cover in Sri Lanka has shown steady decline over the last decade's .Between 1984 and 2005resulted in a reduction of forestland from $84 \%$ to $19 \%$ of land area. According to the data of forest cover assessment in $2010,29.7 \%$ of the total land area or about 1.95 million hectares of Sri Lanka is forested by natural forest. Of these 1.44 million hectares or $21.9 \%$ classified as dense forests (over $75 \%$ canopy cover) rest of 0.51 million hectares or $7.8 \%$ of the land area classified as open forests, Mangrove Forest and Savannah (Edirisinghe et. al, 2012). Other than this, Sri Lanka has about 90,000 hectares of planted forest including Teak, Mahogany, Eucalypts, Pine and other local species.

The Owner of the Sri Lanka's forests lands is Government of Sri Lanka. Government managed all forestlands under the jurisdiction of two institutions called, Department of Forest Conservation and Department of Wildlife Conservation. Conservation forest, Forest Reserves, Proposed Forest Reserves and National Heritage and Wilderness Areas are managed by Department of Forest Conservation. The extent exceeds $17 \%$ of the total land area. In addition, Department of Forest Conservation manages about 90,000 hectares of forest plantations. Department of Wild life Conservation manages approximately 8500 $\mathrm{km} 2$ of the forest area, which occupying $13 \%$ of the total land area. It include Wildlife Protected Areas and Sanctuaries

\section{Forestry Policy changed over time}

\subsection{Period of Kings}

Sri Lanka has a highly developed ancient civilization. Historical literary documents like Mahawansa, Rajaratnakarya and Rajawaliya and ancient inscriptions have proved that Sri Lankan's ancestors were much concerned about the matters related to forests.

Main objective of ancient forest management is provision of forest product while having harmonious relationship with wild lives. The forest nearby village namely, badda, lahaba was an integral part of the village which provide livelihood. Rules of ancient times never allowed the misuse of forest or indiscriminate clearing of forest through the trees and forests were then abundant in the country. In facts they framed laws to protect forest and trees. The Buddhist cleargy used the forest for meditation purposes. Kings used forest for military training and for various martial arts. Forest lands were offered as assets of king and administrators were appointed to look after forests under the rightful ownership of the king.

According to the Mahawansa, in 246 BC, The King Devanampiyatissa established countries first National Park Namely, Mahamevna Uyana, In this period Buddhism was rapidly spread all over the country. King Devanampiyatissa had established incomparable religious and cultural paragon of nonviolence and equality of rights of every living being. This great concept helps to protection of forest and wild life for future generation. Requirement of rules and regulation for the use of forest products while conserving the forest was realized by the King Dutugamunu( 161 to 137 B.C) and established countries first forestry rules. 
Several sources give information about the forest in the country during the final stage of the Sinhala dynasty. Robert Knox (1961 AD) and Vincents (1882AD) mentions about large extent of forests in the kandyan kingdom, and the 30 to 40 miles wide forest strips that have been recognized as boundaries of provinces. Ainslie (1920 AD) reports that Sinhala kings appointed forest administrators. Duties of these administrators are supply wild meat and fruits to the king's palace, prevention of illicit gaming inside the forests, protection of royal trees and Settlement of lands in the forest (Forest Recourses Conservationists, 2010).

\subsection{Period of Colonial}

Since $16^{\text {th }}$ century, the invasion of colonial rules and regulation resulted in a drastic change in land use policy. At first, Portuguese and Dutch occupied the coastal areas of the country, and then the British shifted to the central highlands. There is no written evidence that Portuguese (1505 AD) who subjugated the maritime provinces of the country has done anything to conserve forest. Before colonial invasion, Sri Lanka's forest cover was so extensive. Hence, Portuguese exploited forests without any limitation.

Compare to the Portuguese, the Dutch gave more consideration to the forest and forest product as a valuable thing. Dutch introduce teak and Jack plant in 1680. There is evidence that the Dutch rule treated all trees planted in private and state land as state property. They introduced stringent laws to protect forest plantations. Planting of trees and the protection of forest had been declared as the duty of the village headmen.

With the occupation of country by the British in 1796, many changes took place in regard to the forest. In the early period of the British rule, forests were cut down at very high rate. They indiscriminately destroyed the natural forest strips bordered the mountain range which protected the Kandyan kingdom in order to open access from their territories. In the period of British, they preferred planting of tea, coffee and cinchona. In order to plant these plantation crops the British cut down large extent of forests in upcountry. In the mean time large extents of forests were cleared for chena (Shifting) cultivation by local communities as there was no control. In view of this denudation the British rules introduce various laws to curb the clearing of forest. In order to prevent encroachment, the Crown Lands Encroachment Ordinance No 12.of 1840 was enacted. Laws were introduced in 1848 to control the felling of trees in Crown Lands.

Degradation of forests become worse when the contractors were engaged to extract timber, and the colonial secretary proposed to appoint forest officers to control this situation. In 1873 forest officers were appointed to supply timber for government department. F.C.A Vincent of the Indian Forest service was appointed in 1982 to advice the colonial Government on forestry matters. He produced detailed report about forests in Sri Lanka in the same year. His recommendation includes the appointment of a conservator of forests, introduction of Forest Ordinance, declaration of forest reserves based on policy and regulation of chena (shifting) cultivation. Accordingly, the forest Ordinance No 10 of 1885 was passed (Forest Recourses Conservationists Organization,2010). Moreover, in 1887 the first Conservator of Forests was appointed to forest department. At the turnoff century, staff was appointed to the forest department and Island was divided into several divisions to administer forests. The Forest Ordinance which is in use even today was enacted in 1907 as ordinance No16 of 1907.Ranges and Beats were established in the same period. In 1930, the forest department started deports for timber sales. The forest department was engaged in timber conversion and selling for a long time even after independence. At a meeting chaired by Governor Hurbert Stanley in 1929, the first set of forestry policies was adopted. The policies were as follows

- Providing for self - Sufficiency in wood and other forestry products by utilizing the natural resources available and by regeneration of forest in selected area

- Exporting of such timber and forest product

- To conserve water and preventing soil erosion

- To management of forestry activities while ensuring the protection of the natural habitat of wild plant and animal

In 1934, again the forest administration was divided into two as reserved forest and the other forest (other crown forests). Crown Forests were allotment for commercial purposes and exploitation. They were handed over to the government Agents and reserved forest were kept under the jurisdiction of department of forest (Nanayakkara, 1981).From the inception the control of wild life was under the Forest Department. The Ordinance No 2 of 1937 was enacted as Fauna and flora protection Ordinance. Enacting of Fauna and flora protection Ordinance develop path to create new department after the independence.

\subsection{Post-Independence Period}

Policies related to forest were change with independence in 1948. The Wild Life Conservation Department then known as the Wild Life Department was created in 1949. Out of other Crown Forests handed over to the Government Agents in 1934; forests not below 500 acres in the Dry Zone and not below 50 acres in Wet Zone were re vested with the 
Forest Department in 1952. A new National Forest policy was declared in 1953 with following priorities,

- To Maintain and establish forests for protection of natural resources and indigenous fauna and flora while maintaining the aesthetic, scientific, historical and socio-economic value.

- Increase the supply of small wood for domestic purposes

- Ensure the sustainable productivity of timber and other forest product to full fill countries public requirements such as communication and defense

- To Achieve highest economic benefits through above objectives

\subsection{Period of 1960-1990}

During these thirty years appreciable events were occurred in the forestry field. Special attention was drawn to community participation for forest conservation and forest plantation establishment. State timber cooperation was incorporated in 1968, and timber related commercial activities were vested with this cooperation. A new set of Forest policies were made in 1980.this forest policy created considerable subversion in forestry of the country by addressing the economic consequence of forest resources.

The main objectives of the forest policy of 1980 were,

- To Maintain and establish forests for protection of natural resources and indigenous fauna and flora while maintaining the aesthetic, scientific, historical and socio-economic value.

- Increase the supply of small wood for domestic purposes

- Ensure the sustainable productivity of timber and other forest product to full fill countries public requirements such as communication and defense

- To Achieve highest economic benefits through above objectives

- Incorporate the community participation in forestry sector through the social forestry program

Year 1986 was most important year for Sri Lanka's forestry sector. The first forestry Master plan, a broad, describable, frame work which is applicable for long term was formulated in this year. This Master Plan play significant role in developing the forestry database and technical improvement of forestry sector. (Department of Forest Conservation, 2008). During the early 1990s, institutional reform was initiated in Forestry sector. Moreover, Separate management divisions were formulated within the forest department to implement and monitoring of different forestry activities (Bandarathileke, 1991). All natural forests in the country were set apart for the conservation of soil, water and biodiversity and no extraction of timber is taking place since the moratorium of logging in natural forests imposed in 1990.

\subsection{Period from 1990- Until now}

In 1992-1996 Deforestation was most severe and forest cover is continuing decrease. Also, significant environmental losses were reported during this period. Human animal conflict has been increased due to habitat losses. Rate of Biodiversity reduction has been increased in considerable level, due to massive erosion siltation have been increased. However, inefficient management activities and in equality in utilization of forest resources and other realities recognize the requirement of new forestry policy.

In terms of forestry development, the year 1995 is most important. The new forestry sector policy and Sri Lanka Forestry Sector Master Plan were adopted by government in 1995 is the policy for forest conservation in operation today. Forest laws and regulations are being amended and forest management systems to suit the current and future conditions are being formulated and operated in accordance with this new policy.

The main objectives of new policy were Conservation of natural resources, increase the forest cover and productivity and support the rural livelihood.

The New Forestry Sector Master Plan emphasized ecological, economical, social, political, technical and scientific aspects and overall administrative functions of forestry sector. It has been formulated strong guideline for forestry decision making in local regional and national level. This plan covers 25 years and it will be ended in 2025. Master plan formulated policies in following fields

- $\quad$ State owned forest resources

- $\quad$ private owned forests and trees

- extraction, production, marketing of wood and non wood forest products

- Development of forestry Sector institution

- Policy on inter sectoral linkage

- International forest related conventions

From this components, Policy on management of state forest resources accentuated basically on conservation of existing natural forests, recognized and respect traditional rights, cultural value and religious belief of forest adjacent communities, stimulating rural people to correct use and conservation of multiple use forests, increase the community participation in forestry development activities, rehabilitate degraded forest as other agroforestry systems and plantation forestry to meet the 
community's needs, strengthen the policies and legal reforms to improve the productivity of forestry institutions.

Later on, the existing Forest Ordinance was amended in 2009 (Act No 65 of 2009) was the ordinance amended lastly. The Forest ordinance and regulations published under the ordinance have stipulated provisions to protect forest and meaningful implementation of the National Forestry Policy and the Forestry Sector Master Plan.

\section{The Way forward for sustainable Forest Management}

Forestry sector in Sri Lanka can be categorized as a key component of Nation economy. Unfortunately, many factors have hindered its sustainable development. Consider the forest policy; it is a framework for the distribution of rights in terms of utilization of the resources in a sustainable manner that would not hinder the regeneration capacities of those same resources. Therefore identification of issues of forest policy is necessary for find out solution for future sustainability of forestry sector. The forest policy issues to be addressed will vary according to the ecological, social and economic factors. Some key issues and recommendations discuss here

\section{Political and institutional coordination}

Forest conservation is a subject which is much different from the forest protection .it goes beyond forest protection encompassing the concept of environment friendly management. It is not easy task for forest department. Better results can be achieved through effective involvement and collaboration of all stakeholders in forestry sector. Coordination among key institutions such as Department of Wildlife Conservation and Central Environmental Authority, State timber cooperation is lacking at the moment. Especially in the case of management and protection activities, there are certain disparities between Forest Department and Central Environmental Authority. Also in Sri Lanka forestry sector political influence are extremely wide. Therefore, government and political parties has the responsibility of obtaining the unanimity of those parties to implement forest policies correctly, practically and effectively. Strong institution coordination and efficient political involvement is an essential for sustainable Forest management

\section{Knowledge ,education and capacity building in implementing policy and Law}

The forest Ordinance No 16 of 1907 amended at several occasions is still the Forest law enforced in the country. There are other ordinance and acts which support the implementation of the forest law. In addition, Provisions in the constitution, the supreme law of the country, in regard to the environment and natural resources illustrate the responsibility and duties of the government and the public. The constitution of Sri Lanka (1978), the supreme law of the country in regard to the environment and natural resources illustrate following two clauses for the government and public. Article 27 (14) of chapter (vi) in the constitution states that the "state shall protect, preserve and improve the environment for the benefit of the community." Article 28 (f) Says that "It is the duty of every person in Sri Lanka to protect nature and conserve its riches." These articles invite attention of everybody. In brief though, these two articles define the responsibility of protecting all aspects of the environment. Therefore, there is a strong legal system for the protection of forest in Sri Lanka. It is well inscribed in books of law. Nevertheless, it is not going to prevent the destruction of Sri Lanka's forest, until laws are put in to practice strongly, correctly and effectively.

There is strong barrier in the enforcement of the law. Some officers who enforce the law do not have the commitment to apply ever changing forest law and policy to suit the context and the time due to lack of sufficient knowledge in forest law and policy. Therefore awareness programs are extremely necessary to address officers and others parties involved in forestry sector.

\section{Policy Formulation approach}

The Forest policy in Sri Lanka is a top down approach. The top-down policy formulation does not regard the potential and needs of local people. Only one central goal is applied for all forest area regardless of differences in social and economic contexts of each forest and people around it. Policy development, formulation and implementation must be in compatibility with the cultural community and should be done locally. The policy makers should hear public opinion in particular on land use and forest policy. They should also view possible trends by study the past situation of community.

\section{New policy}

The forest is playing a vital role in world energy security and climate change mitigation. However, there are trade-offs among these two sectors. All over the world there is conflict between various climate change mitigation functions and other functions of the forest. Therefore, should have divers potential roles for the mitigation and adaptation to climate change and enhance energy security. Sri Lanka joined UN-REDD (United nations - Reduce Emission from Deforestation and forest Degradation) Program in 2009 and the national program was approved for 
funding in September 2012. This provides an ideal opportunity to benefit from country's natural forests set aside for conservation. Although, countries Bio energy requirement at the critical point. However, the formulation of policy for both climate change mitigation and energy security is complicated. More consideration should be focus on future climate change regime and future energy demand. Therefore, Strong Scientific commitment is essential for sustainability of these two sectors. According to estimation in year 2002, Sri Lankans dependency of petroleum products was around $82 \%$ ( Rajmohan and Weerahewa,2016 ). Due to high dependency and increasing demand of petroleum products Sri Lankan economy face severe problems during the world oil crisis. However, a tree is a major carbon sequesters which can produce Bio energy. The correct use of tree to produce bio energy could be helpful to fulfill energy demand and mitigate Climate change. Hence, in a sustainable development perspective, the supply of bio energy through the forestry sector must be included into the forest sector policy.

\section{Conclusion}

The forest policy is meant to provide a framework for the distribution of rights in terms of utilization of the resources in a sustainable manner. The forest policy modified in 1995 have broadly addressed most of forestry sector issues in the country and drastic reduction of forest cover has been reduced in to some extent. However, According to the government action plan, the forest cover of Sri Lanka expected to rise to $35 \%$ of the total land area by 2020 from the present level of $27.9 \%$. Hence, forest policy implementation mechanism must be strong and efficient.

Currently, Sri Lanka's social and economic development accelerated the use of natural resources including forest resources, whereas ecological value of forest was neglected. Some policies were formulated without analysis real forest situation and ignore the need of people. The policies do not specify the responsibility agencies to take action, planning and monitoring. Therefore, success of implementation of forest policies is quite low than expected level.

Better delivery of Knowledge from top to bottom level with focus on each part of forestry sector and further strengthen and reform of the stakeholder institutions is much needed. The commitment of government and active participation of all stake holders could make Sri Lanka green island with sustainable forest management and bring about ecological security and socio economic prosperity.

\section{Acknowwledgement}

Special thanks is extended to APFNet (Asia Pacific Network for sustainable Forest Management and Rehabilitation) for granting the scholarship for the first author to complete M.Sc degree in Forest Economic and Management in Beijing Forestry University.

\section{References}

1. Bandaratillake, H. M. (1991). National Forest Policy and Strategies for conservation of forest resources in Sri Lanka, Proceeding of the Second Regional Workshop on multipurpose Trees, Kandy, Sri Lanka - April 1991.

2. Department of Forest Conservation (2008).Activity guideline. Baththaramulla: Natural Resources Management Project

3. Edirisinghe E.A.P,N., Ariyadasa K.P., and Chandani R.P.D.S. (2012). Forest cover assessment in Sri Lanka. Sri Lanka Forester, 34, 1-12.

4. Food and Agriculture Organization of the United Nations. (2016, April 21). Sustainable Forest Management. Retrieved July 20, 2016,From http://www.fao.org/forestry/sfm/85084/en/

5. Forest Recourses Conservationists Organization.(2010).Law For the Conservation of Forest

(3-5) Forest Recourses Conservationists' Organization, Department of Forest Conservation, Sri Lanka.

6. Gunatilake, H. M.(1998). The role of rural development in protecting tropical rainforests: evidence from Sri Lanka. Journal of Environmental Management, 53(3), 273-292.

7. Gunasena, H.P.M. (1993). Forest policies of Sri Lanka. In FAO (1993), Forestry policies of selected countries in Asia and the Pacific. Rome: FAO Forestry Paper 115.

8. Hewage, T. (1995). National Forest Policy for Sustainable Development in Forestry for Development - Proceedings of the Annual Forestry Symposium 1995, Ed. By Hiran Amarasekera et al. University of Sri Jayewardenepura, 1996.

9. Maddugoda, P. (1991) "Experience of community forestry in Sri Lanka," Proceedings from second regional workshop on multi-purpose trees. Kandy, Sri Lanka 5-7 April 1991

10. Nanayakkara, V.R. (1981) National forest policy development in Sri Lanka. The Sri Lanka Forester 15 (1 and 2),5-11

11. Rajmohan,V.R.,Weerahew ,J. (2016 )Household Energy Consumption patterns in Sri Lanka. Retrieved from. http://www.slageconr.net/sjae/sjae91f/sjae09104.pdf

12. Van Kooten, G. C. and Bulte, E. H. (2000). The economics of nature: managing biological assets. Blackwells.

13. World Bank (1992), World Development Report, Development and the Environment.

14. Zoysa de Mangala, A review of Forest Policy Trends in Sri Lanka, Policy Trend Report 2001, 57-68. 